\title{
EFEKTIVITAS PEMBERIAN JAMUR TIRAM PUTIH (Pleurotus ostreatus) TERHADAP PENURUNAN KOLESTEROL PADA TIKUS PUTIH (Rattus novergicus)
}

\author{
*Rachmat Faisal Syamsu
}

\section{PENDAHULUAN}

Kolesterol dalam darah merupakan salah satu masalah besar yang dihadapi oleh masyarakat di dunia. Kelebihan kolesterol dalam darah (hiperlipidemia) akan mengakibatkan penyakit jantung dan stroke. Menurut World Health Organization (WHO) dan Organisasi Federasi Jantung Sedunia (World Heart Federation) penyakit jantung saat ini menjadi penyebab utama kematian di negara-negara Asia dan Eropa. Setiap tahun diperkirakan 17,3 juta orang meninggal akibat penyakit kardiovaskular. Sebanyak 11,1 juta diantaranya terjadi akibat penyakit jantung dan 6,2 juta akibat stroke. Dimana 78\% kematian global akibat penyakit jantung terjadi pada kalangan masyarakat miskin dan menengah. Di Indonesia pada tahun 2012 penyakit jantung menduduki peringkat pertama yang menyumbang angka kematian. Angka kematian akibat kejadian penyakit jantung kemudian semakin meningkat sebesar 37\% dari angka 16,7\%. Menurut hasil Riset Kesehatan Dasar (Riskesdas) tahun 2013, menjelaskan bahwa prevalensi penyakit jantung dan stroke semakin meningkat seiring peningkatan umur .(WHONCD Country Profil,2014)

Berbagai upaya telah dilakukan untuk menangani hiperlipidemia, antara lain melalui perubahan gaya hidup seperti terapi diet, yaitu dengan mengkonsumsi serat, ikan,mengurangi daging, mengkonsumsi sumber lemak tak jenuh (MUFA dan PUFA). Untuk mendukung upaya terapi diet, perlu diikuti upaya penunjang yaitu menurunkan berat badan dan olahraga. Dimana Perubahan gaya hidup ini nantinya akan sangat erat hubungannya dengan peningkatan dan 
penurunan kadar kolesterol dalam darah. Penurunan kadar kolesterol sebesar $1 \%$ akan menurunkan risiko penyakit jantung sebesar $2 \%$. (Orey, C. 2008)

Penggunaan obat sintetis dapat menimbulkan efek samping seperti alergi atau menyebabkan gangguan fungsi organ lain. Untuk itu, perlu dicarikan obat alternatif dari bahan alami. (Orey, C. 2008)

Jamur tiram putih telah dikenal masyarakat sebagai bahan pangan sejak lama. Jamur tiram putih memiliki kandungan gizi yang baik yaitu kadar protein dan serat tinggi, tetapi rendah lemak. Di samping itu, beberapa penelitian menunjukkan diet Jamur tiram putih memiliki aktivitas hipokolesterolemik dengan menurunkan kadar lipid darah, yaitu total kolesterol, trigliserida, dan rasio LDL/ HDL. Jamur tiram putih mampu meningkatkan ekskresi lipid dan kolesterol melalui feses. Pemberian Jamur tiram putih mampu menurunkan lipid aterogenik, seperti LDL, dimana LDL merupakan lipid aterogenik yang jika teroksidasi akan meningkatkan resiko terjadinya aterosklerosis dan penyakit jantung koroner. (Alam,dkk: 2011)

Tikus putih jantan (Rattus novergicus) digunakan sebagai hewan coba karena termasuk golongan omnivora yang memiliki alat pencernaan dan kebutuhan nutrisi yang hampir sama dengan manusia, memiliki siklus hidup yang relatif panjang, dan dapat mewakili mamalia termasuk manusia. Jenis kelamin jantan digunakan agar tidak terpengaruh oleh siklus hormonal. (Orey, C. 2008)

\section{METODE PENELITIAN}

Untuk membuktikan apakah Jamur Tiram putih dapat menurunkan kadar kolesterol pada tikus putih jantan yang dibuat hiperlipidemia dengan menggunakan obat simvastatin sebagai pembanding, maka peneliti melakukan penelitian ini. 


\section{Jenis dan Rancangan Penelitian}

Jenis penelitian ini adalah eksperimental laboratorium. Dipilih jenis ini karena baik pada sampel maupun perlakuan lebih terkendali, terukur dan pengaruh perlakuan lebih dapat dipercaya. Rancangan penelitian yang digunakan adalah rancangan dengan kelompok kontrol (The Pre and Post Test Control Group Design), yaitu dengan melakukan pengukuran atau observasi sebelum dan setelah perlakuan diberikan.

\section{Besar Sampel Penelitian}

Pada penelitian in vitro ini sampel diperhitungkan dengan menggunakan rumus untuk menghitung jumlah sampel minimal pada hewan coba dengan menggunakan rumus federer 1977. (https://www.academia.edu/5740261/Jumlah_sampel).

$$
\begin{aligned}
& (\mathrm{n}-1) \mathrm{x}(\mathrm{t}-1) \geq 15 \\
& \mathrm{n}=\text { jumlah sampel } \\
& \mathrm{t}=\text { jumlah perlakuan } \\
& \text { Dalam penelitian ini dilakukan empat perlakuan sehingga diperoleh jumlah sampel } \\
& (\mathrm{n}-1)(4-1)>15 \\
& (\mathrm{n}-1)(3)>15 \\
& (\mathrm{n}-1)=5 \\
& \mathrm{n}=6
\end{aligned}
$$$$
\mathrm{t}=\text { jumlah perlakuan }
$$

\section{Analisa Data}

Dalam penelitian ini, data yang didapatkan dianalisa menggunakan uji statistik parametrik sebagai berikut : (Dahlan MS. 2011) 
a. Data yang dihasilkan homogen dan normal, maka dilakukan uji T-tes untuk membandingkan kadar rerata masing-masing kelompok dengan kelompok yang lain, dan menggunakan tingkat kemaknaan $95 \%(a=0,05)$.

\section{Prosedur Penelitian}

\section{Persiapan Hewan Coba}

Hewan coba diadaptasaikan terhadap lingkungan kandang di laboratorium farmakologi fakultas farmasi UMI. Hewan coba di beri makanan standar dan minum setiap hari secara ad libit um (sesukanya), dan ditimbang kemudian dikelompokkan secara acak.

\section{Perlakuan Hewan Coba}

Sampel dikelompokkan menjadi empat kelompok, yaitu:

a. Kelompok I (kontrol negatif), terdiri dari 6 ekor tikus sehat yang menjadi kelompok kontrol yang diberi makanan standar tikus dan minum (aquadest steril) tanpa pemberian Jamur Tiram Putih dan diet hiperlipidemia. Waktu perlakuan diet adalah 14 hari karena pemberian diet hiperlipidemia memberi kenaikan kadar kolesterol dalam darah dalam jangka waktu tersebut. Setelah itu hewan coba dilakukan pengambilan sampel darah kadar kolesterol.

b. Kelompok II (kontrol positif/ perlakuan hiperlipidemia) terdiri dan 6 ekor tikus sehat yang menjadi kelompok perlakuan yang diberi makanan standar yang dicampur dengan diet hiperlipidemia (lemak kambing/lemak sapi / hati ayam / tepung / telur puyu 10\%, minyak kelapa 9\%, minyak jagung 1\%) dan minum (aquadest steril). Setelah 14 hari, hewan coba dilakukan pengambilan sampel darah kadar kolesterol.

c. Kelompok III (perlakuan hiperlipidemia + Jamur Tiram Putih) terdiri dan 6 ekor tikus sehat yang menjadi kelompok perlakuan yang diberi makanan standar yang dicampur dengan diet hiperlipidemia (lemak kambing / lemak sapi / hati ayam / 
tepung / telur puyu 10\%, minyak kelapa 9\%, minyak jagung 1\%), minum (aquadest steril), dan Jamur Tiram Putih secara per oral menggunakan sonde lambung. Setelah 14 hari , hewan coba dilakukan pengambilan sampel darah kadar $\quad$ kolesterol.

d.Kelompok IV (perlakuan hiperlipidemia + obat simvastatin) terdiri dan 6 ekor tikus sehat yang menjadi kelompok perlakuan yang diberi makanan standar yang dicampur dengan diet hiperlipidemia (lemak kambing / lemak sapi / hati ayam / tepung / telur puyu 10\%, minyak kelapa 9\%, minyak jagung 1\%), minum (aquadest steril), dan larutan simvastatin diperoleh dengan melarutkan 0.18 zat aktif simvastatin ke dalam $5 \mathrm{ml}$ aquades. Untuk tikus dengan derat badan 150 gr diperlukan $\quad 3.75 \mathrm{ml}$ larutan simvastatin. Larutan simvastatin diberikan dengan menggunakan NGT dan syringe.

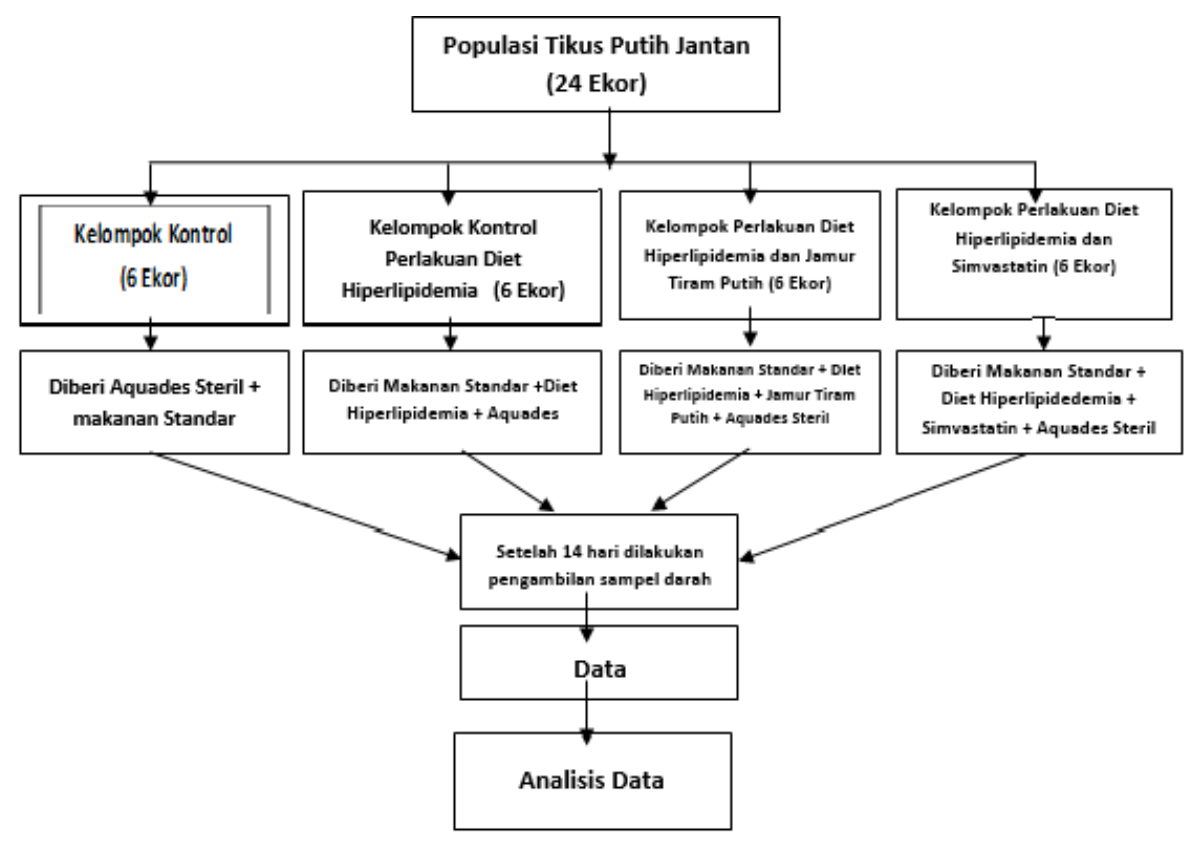

\section{Pengambilan Sampel Darah}

Prosedur pengambilan sampel darah adalah sebagai berikut :

a. Pengambilan darah vena di ekor sebanyak 2- 3 cc 
b. Segera setelah darah keluar, darah dimasukkan ke strip pada alat ukur.

c. Sampel darah diperiksa dengan menggunakan alat pengukur kadar kolesterol merk Nesco.

\section{HASIL PENELITIAN DAN PEMBAHASAN}

\section{HASIL}

Berikut hasil penelitian yang disajikan dalam bentuk tabel ;

\begin{tabular}{|c|c|c|}
\hline \multirow[t]{2}{*}{$\begin{array}{c}\text { NAMA } \\
\text { KELOMPOK }\end{array}$} & \multicolumn{2}{|c|}{$\begin{array}{l}\text { KOLESTEROL TOTAL } \\
(\mathbf{m g} / \mathbf{d l})\end{array}$} \\
\hline & SEBELUM & SESUDAH \\
\hline \multirow{4}{*}{$\begin{array}{l}\text { Kelompok } 1 \\
\text { Kontrol Negatif }\end{array}$} & 153 & 148 \\
\hline & 167 & 148 \\
\hline & 154 & 150 \\
\hline & 161 & 160 \\
\hline \multirow{4}{*}{$\begin{array}{l}\text { Kelompok } 2 \\
\text { Kontrol Positif }\end{array}$} & 159 & 221 \\
\hline & 173 & 232 \\
\hline & 176 & 212 \\
\hline & 163 & 216 \\
\hline \multirow{4}{*}{$\frac{\text { Kelompok } 3}{\text { Jamur Tiram Putih }}$} & 177 & 157 \\
\hline & 168 & 103 \\
\hline & 161 & 117 \\
\hline & 175 & 136 \\
\hline \multirow[t]{4}{*}{ Kelompok 4} & 163 & 128 \\
\hline & 170 & 135 \\
\hline & 154 & 133 \\
\hline & 172 & 118 \\
\hline
\end{tabular}

Tabel 1.1 Hasil Penelitian Nilai Kadar Kolesterol Total Tikus Putih.

Grafik 1.1 Rerata Kadar Kolesterol Total Tikus Putih 


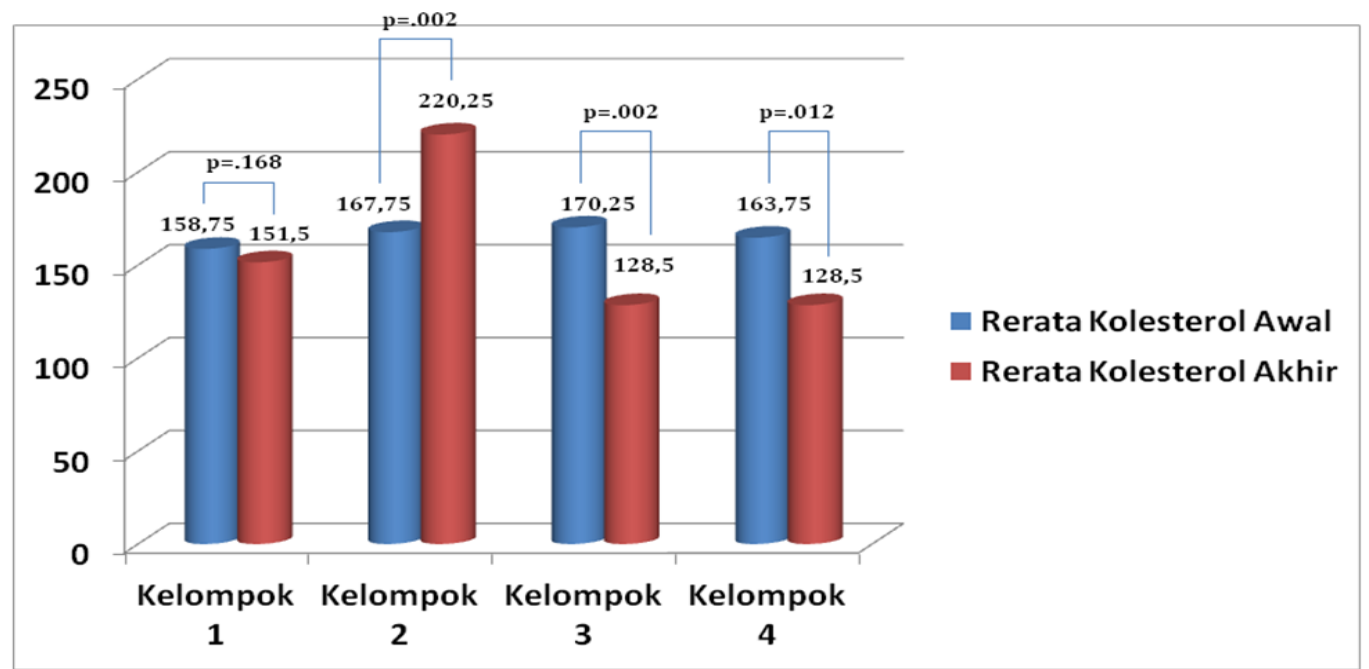

Penelitian ini dilakukan di laboratorium Farmakologi Fakultas Farmasi dengan jumlah sampel sebanyak 24 ekor. Selama masa perlakuan diminggu pertama tanggal 23 sampai 30 agustus 2016 ada 6 ekor tikus yang mati. Dikelompok 1 (kontrol negatif) sebanyak 2 ekor, kelompok 3 (perlakuan jamur tiram putih) sebanyak 2 ekor, dan kelompok 4 (perlakuan simvastatin) sebanyak 2 ekor. Diminggu kedua perlakuan tanggal 31 agustus sampai 7 september 2016 ada 2 ekor tikus lagi yang mati, dikelompok 2 (kontrol negatif) sebanyak 2 ekor. Hingga total sampel yang tersisa setelah penelitian selesai adalah 16 ekor dengan masing-masing kelompok berjumlah 4 ekor. Penelitian tetap dilanjutkan karena perlakuan sudah diberikan.

\section{PEMBAHASAN}

Penelitian ini dilakukan untuk mengetahui efek pemberian jamur tiram putih (Pleurotus ostreatus) terhadap perubahan kolesterol dalam darah tikus putih jantan (Rattus Novergicus) yang diberi tinggi lemak dengan menggunakan obat simvastatin sebagai pembanding hasil sebelum dan sesudah penelitian. Penelitian ini dibagi menjadi 4 kelompok yaitu, kelompok 1 sebagai kelompok kontrol negatif yang diberi makanan dan minuman standar, kelompok 2 kontrol positif yang diberi diet tinggi lemak, kelompok 3 jamur tiram putih yang diberi diet tinggi lemak dan jamur tiram putih 0,4 ml/gr/200grBB/hari, serta kelompok 4 simvastatin yang diet tinggi lemak dan obat simvastatin 0,18 mg/hari/200grBB.

\section{Pengaruh pemberian jamur tiram putih terhadap kolesterol total.}


Berdasarkan data yang diperoleh, pemberian jamur tiram putih pada kelompok 3 yang diberi diet tinggi lemak setelah diukur kadar kolesterol totalnya mengalami perubahan antara sebelum dan sesudah perlakuan. Dengan nilai rerata sebelum perlakuan adalah 170,25 dan sesudah perlakuan 128,5 dan selisih delta mean (sesudah-sebelum = -38,5). Ini berarti jamur tiram putih mampu menurunkan 24,52\% kadar kolesterol total tikus putih yang diberi diet tinggi lemak selama 14 hari. Setelah itu di lakukan uji paired sample t-Test antar nilai rerata tersebut diperoleh hasil sig $=0.002(p<0.05)$ yang berarti nilai kolesterol pada sebelum dan sesudah perlakuan adalah tidak sama,berbeda signifikan. Hasil ini mendukung teori penelitian sebelumnya bahwa pemanfaatan Jamur tiram putih (Pleurotus ostreatus) yang terbukti terdapat kandungan niasin dan serat sehingga mampu menurunkan kadar kolesterol (Lestariani, 2009).

Teori lain mengatakan bahwa para ahli di luar negeri telah berhasil mengekstrak jamur tiram putih untuk mengambil senyawa aktif lovastatin, yang berguna sebagai penurun kolesterol. Unsur pembentuk jamur tiram diantaranya air, karbohidrat, protein, vitamin (B1,B2, biotin, niasin, dan C),kalium, fosfor, ferrum, natrium, magnesium, cuprum, dan lemak. Mineral yang bersifat logam kadarnya rendah sehingga aman dikonsumsi setiap hari. Adapun lemak pada jamur tiram $72 \%$ adalah asam lemak tak jenuh sehingga dianjurkan bagi penderita kolesterol tinggi. Selain itu, kandungan asam amino essensial pada jamur tiram berguna dalam proses metabolisme tubuh karena tubuh kita tidak memproduksinya. Jenis asam amino essensial itu adalah methionin, tryphofan, theonon, lysine, valin,leusin, histidin, dan fenil alanin. Berdasarkan penelitian United States Drugs and Administration, menunjukkan bahwa tikus yang diberi pakan jamur tiram selama 3 minggu, kadar kolesterolnya turun hingga 40\% dibandingkan yang tidak diberi pakan jamur tiram. Kesimpulannya, jamur tiram bisa di terapkan pada manusia penderita hiperkolesterol. (Rumah Sakit Universitas Airlangga : http://rumahsakit.unair.ac)

Dalam penelitian lain dikatakan bahwa pengolahan jamur tiram putih dengan cara penggorengan sedikit lebih baik dalam menurunkan kolesterol dibandingkan dengan dipanggang (Sharma P. H.S dkk, 2011).

Pada penelitian Tutut Elok Prasetyowati (2012) dikatakan bahwa, bahwa pemberian ekstrak jamur tiram putih (Pleurotus ostreatus) berpengaruh terhadap penurunan kadar kolesterol dan bobot tubuh tikus putih (Rattus norvegicus L.). Untuk kadar kolesterol darah tikus putih dosis yang optimum menurunkan adalah ekstrak jamur tiram putih 0,09 gr/hari dengan penurunan sebesar $63,33 \mathrm{mg} / \mathrm{dl}$. Selanjutnya untuk bobot tubuh tikus putih dosis yang optimum 
menurunkan adalah ekstrak jamur tiram putih 0,09 gr/hari dengan penurunan sebesar 12,67 $\mathrm{mg} / \mathrm{dl}$ meskipun penurunannya belum mencapai kadar kolesterol dan bobot tubuh normal tikus putih. Berdasarkan hasil penelitian dan uji validasi ahli, penelitian ini baik dijadikan sebagai alternatif pilihan. (Tutut,E.P,2012)

\section{KESIMPULAN DAN SARAN}

\section{Kesimpulan}

Jamur tiram putih (Pleurotus ostreatus) memiliki kemampuan untuk menurunkan kadar kolesterol dalam darah tikus putih (Rattus Novergicus) sebesar 24,52\% dengan dosis pemberian $0,4 \mathrm{ml} / \mathrm{gr} / 200 \mathrm{grBB} / \mathrm{hari}$ yang diberi diet tinggi lemak selama 14 hari.

\section{Saran}

Untuk peneliti berikutnya, dilakukan ekperimen dengan memperhatikan mekanisme kerja dan dosis yang paling tepat dari jamur tiram putih (Pleurotus ostreatus) dalam perubahan kadar kolesterol pada sampel penelitian seperti manusia. 


\section{DAFTAR PUSTAKA}

Ahmad,F. 2008. Metabolisme Lipoprotein. Jakarta: [24 November 2010].

Alam, N., K.N. Young, T.S. Lee, and U.Y. Lee. 2011. "Hypolipidemic activities of dietary Pleuratus ostreatus in hypercolesterolemic rats, Mycobiology”, vol.39(1), pp.45-51.

Chesebro,J.H. et al.2006. Thrombolysis in myocardial infarction. (TIMI) trial, Phase I A.

Dahlan MS. 2011. Statistik untuk kedokteran dan kesehatan. Jakarta. Salemba medika.

Fauzi,F.2011.Pengobatan Hiperlipidemia. http://www.faikshare.com ～(27 Mei 2011).

Ganong, W.F. 2009. Buku Ajar Fisiologi Kedokteran Edisi: 20. Jakarta: EGC.

Https://www.academia.edu/5740261/Jumlah_sampel

Indranila. 2008. Hubungan Lipoprotein (a) dengan Mikroalbuminuaria. UNDIP.

Okada, T., Ayada, K., Usui, S., Yokota, K., Cui,and Oguma, K. 2007. Antibodies against heat shock protein 60 derived from Helicobacter pylori Diagnostic implications in cardiovascular disease. Journal of Auitoimmunity, $29: 106-15$.

Orey,C. 2008. Khasiat Jamur Tiram Ala Meditreania. Jakarta : Penerbit Hikmah (PT Mizan Publika).

Purborisanti DK. 2012. Pengaruh Polifenol Buah Tin (Ficus Carica Linn.)terhadap Pembentukan Foam Cell Pada Aorta Tikus (Rattus Norvegicus L.) Dengan Diet At e $r$ oge ni $k$. [ Tuga s Ak hi $\mathrm{r}$ ] . T i da k Di t er bi $\mathrm{t}$ ka $\mathrm{n}$. Universitas Brawijaya, Malang.

Sartika, R.A.D. 2008. Pengaruh Asam Lemak Jenuh, Tidak Jenuh, dan Asam Lemak Trans terhadap Kesehatan. Jurnal Kesehatan Masyarakat Nasional Vol. 2 No. 4 [serial online]. http://isjd.pdii.lipi.go.id/admin/jurnal/2408154160.pdf (20 Mei 2011).

Sharma, P. H.S. Gujral, and C.M. Rosell, 2011, "Effects of roasting on barley $\beta$-glucan, thermal, textural, and pasting properties.Journal of Cereal Science”, vol.53, pp.25-30.

Suryaningrum, B. 2012. Pertumbuhan Dan Produktivitas Jamur Tiram Putih ～(pleurotus Ostreatus). Duta Wacana University.

WHO-NCD Country Profil, 2014 
Widyaningsih, W., Mulyono, dan Rosidi, U. E.2007, Efek Ekstrak Etanol Belimbing Manis (Averrhoa carambola L) sebagai Penurun Kadar Kolesterol, Media Farmasi, Vol. 6, 9-14.

Tutut,E.P. 2012. Pengaruh Ekstrak Jamur Tiram (pleurotus ostreatus) terhadap Penurunan Kadar Kolesterol dan Penurunan Bobot Tubuh Tikus Putih. Program Studi Pendidikan Biologi Jurusan Pendidikan MIPA Fakultas Keguruan dan Ilmu Pendidikan : Universitas Jember. 